JOURNAL OF

BUSINESS

UNIVERSIDAD DEL PACÍFICO

UNIVERSIDAD

\title{
The Role of Responsible Management in Job Satisfaction and Performance Within Banking Firms
}

\author{
Edith Patricia Borboa Álvarez \\ edith.borboa@itson.edu.mx \\ Instituto Tecnológico de Sonora (México) \\ Luis Enrique Valdez Juárez \\ levaldez@itson.edu.mx \\ Instituto Tecnológico de Sonora (México) \\ Roberto Limón Ulloa \\ rlimon@itson.edu.mx \\ Instituto Tecnológico de Sonora (México) \\ Oscar Ernesto Hernández Ponce \\ ohernadez@itson.edu.mx \\ Instituto Tecnológico de Sonora (México) \\ Javier Saucedo Monarque \\ jsaucedo@itson.edu.mx \\ Instituto Tecnológico de Sonora (México)
}




\begin{abstract}
In recent years the need for responsible management of financial institutions, in terms of organizational commitment to supporting society and strategies for sustainable economic development, has become increasingly pressing. The aim of this article is to determine the influence that management has on job satisfaction and performance at banking firms based in northeast Mexico. The primary data were obtained using an instrument applied to management-level employees of public and private banking firms in the cities of Ensenada and Tijuana in Baja California; and Hermosillo, Guaymas, Ciudad Obregón, and Navojoa in Sonora. The statistical technique of linear regression modeling was used to analyze and validate the results, with the aid of the Statistical Package for the Social Sciences (SPSS), version 25. The results show that managerial commitment is a key factor in the organizational performance of responsible banking. Thus, the greater the management responsibility for socially responsible actions, the stronger the positive influence on employees' job satisfaction in the sector. It was also found that the banks are generally well predisposed to corporate social responsibility, and that commitment has a positive and significant relationship with the performance of these institutions.
\end{abstract}

\title{
Resumen
}

En los últimos años, la necesidad de una gestión responsable de las instituciones financieras, en términos de compromiso organizacional para apoyar a la sociedad y estrategias para el desarrollo económico sostenible, se ha vuelto cada vez más urgente. El objetivo de este articulo es determinar la influencia que tiene la gerencia en la satisfacción laboral y el desempeño en las empresas bancarias ubicadas en el noreste de México. Los datos primarios se obtuvieron utilizando un instrumento aplicado a empleados de nivel gerencial de empresas bancarias públicas y privadas en las ciudades de Ensenada y Tijuana en Baja California; y Hermosillo, Guaymas, Ciudad Obregón y Navojoa en Sonora. Se utilizó la técnica estadística de modelos de regresión lineal para analizar y validar los resultados, con la ayuda del Statistical Package for the Social Sciences (SPSS), versión 25. Los resultados sugieren que el compromiso gerencial es un factor clave en el desempeño organizacional de banca responsable. Así, a mayor responsabilidad gerencial hacia las acciones socialmente responsables, mayor será la influencia positiva en la satisfacción laboral de los empleados del sector. También se encontró que los bancos, en general, esta bien predispuestos a la responsabilidad social empresarial, y que el compromiso tiene una relación positiva y significativa con el desempeño de estas instituciones.

\section{Keywords:}

Management, job satisfaction, social responsibility, organizational commitment, performance. 
Borboa-Álvarez, E.P., Valdez Juárez, L.E., Limón-Ulloa, R., Hernández-Ponce, O.E. and Saucedo Monarque, J. (2020) The Role of Responsible Management in Job Satisfaction and Performance Within Banking Firms, Vol.12(1): 82-102

\section{Introduction}

Companies across the globe are answering calls to report their social contributions, a trend from which the Mexican Financial System is not exempt. This has compounded both the importance of social responsibility and expectations for the introduction of indicators that promote transparent communication and assessment of performance in the banking sector, which now constitutes a challenge that banks must meet.

The present study centers on corporate social responsibility (CSR) within the banking sector in the Mexican states of Baja California and Sonora, with the aim of advancing the theory and contributing empirical evidence about management practices related to job satisfaction and organizational performance.

According to the Mexican Banking Association (Asociación de Bancos de México, ABM, 2018) banks are one of several types of financial intermediaries in the MFS that attract, administer, and invest the public's savings. Others include insurance companies, bonding companies, lessors, and investment management companies. But banks, which lend their customers' savings to other customers in need of financing for a range of purposes, are the most important of these intermediaries.

Banking in Mexico is under constant pressure from social organizations, labor unions, human capital, customers, shareholders, the community, academia, government authorities, and other stakeholders to comply with its social, environmental, and corporate governance responsibilities. In this context, financial institutions are required to recognize the importance of acting responsibly. But despite all the initiatives, guides, and indicators led by domestic and international groups and agencies to determine whether banking management is responsible, there are still few banks that apply CSR as part of a convincing business strategy. Moreover, the social contribution of the banking sector in certain Mexican communities has not yet been clearly ascertained. The present study therefore seeks to enhance understanding of this topic and to present new possibilities for analysis (Borboa Álvarez \& Delhumeau Rivera, 2018).

This study also explores business ethics as far as it affects aspects such as: labor conditions, job satisfaction, collaboration with stakeholders, compliance with legal obligations, environmental protection, and, above all, respect for human rights (Morata et al., 2010). Jin, Drozdenko, and DeLoughy (2013) propose that financial organizations become more ethical and socially responsible by adopting core organic values such as being democratic, open, entrepreneurial, creative, and stimulating, while distancing themselves from mechanistic values that can culminate in rigidity and authoritarianism.

From a similar perspective, González and Gutiérrez (2012) argue that the environment in which these organizations operate is fundamental for the social and economic development of any country, and that responsible management is of particular importance in the financial services sector(Miralles Marcelo et al., 2012), since its activities have major repercussions on overall economic activity and the assets of individuals.

The present study entails an analysis of banking practices in the states of Baja California and Sonora-a little-studied area to date-given the urgent need to improve our 
Borboa-Álvarez, E.P., Valdez Juárez, L.E., Limón-Ulloa, R., Hernández-Ponce, O.E. and Saucedo Monarque, J. (2020) The Role of Responsible Management in Job Satisfaction and Performance Within Banking Firms, Vol.12(1): 82-102

understanding of the management factors that influence commitment, job satisfaction, and organizational performance.

The paper is structured as follows: the first section presents a review of the literature and related empirical studies. The second part analyzes the theoretical model, the methodology, and the hypotheses to be tested. The third section analyzes and discusses the results. Finally, the conclusion sets forth the limitations and future lines of research.

\section{Literature review}

The major studies on CSR in recent decades have drawn on Carroll $(1991,2016)$ and his CSR pyramid, which proposes the simultaneous execution of initiatives across ethical, legal, and economic dimensions to achieve responsible results in business and financial performance. While the main theoretical strands have focused on the general benefits CSR offers managers, executives, and shareholders, Lasrado and Zakaria (2020) argue that responsible leaders should create organizational cultures that promote ecological behavior among their employees. In turn, other classical researchers have centered on the benefits shared among all stakeholders (Friedman, 1970; 2007). More recent literature on CSR has confirmed that companies that launch such initiatives have become drivers of social and economic development (Gallardo-Vázquez et al., 2019).

The Mexican Banking Association (ABM 2018, 2020) has argued that banking makes considerable social contributions to the development of Mexico. For instance, in 2013 the sector set in motion various programs aimed at improving customer service, providing professional training, developing new social investment products, and expanding coverage of banking services. From 2014 to 2017, Mexican banking stepped up its corporate volunteering initiatives, sustainable development assistance, and natural relief aid. However, the difficulty in reconciling economic and social profitability means that, at times, the latter weighs less heavily on the commercial scale, and loses out to financial imperatives (Borboa Álvarez \& Delhumeau Rivera, 2018).

The literature on CSR implementation in Latin America-and in Mexico, with regard to banks in particular-is still somewhat underdeveloped, and the present study seeks to fill the gap. This is important given the considerable variance when it comes to CSR adoption, management, and orientation, spanning a range of industries and sectors as well as different regional, national, and international contexts (Maon, Swaen \& Lindgreen, 2017). For its part, the banking sector has not pursued a strategic approach to CSR (Sánchez, De la Cuesta-Gonzalez, \& Paredes-Gazquez, 2017). Thus, there is a need for further empirical research in this field (Engert, Rauter \& Baumgartner, 2016), especially since the limited available public information about banking may be circumstantial; for instance, it may be prepared in compliance with the recommendations of a public agency (such as the banking social responsibility and sustainability reports for the MBS) or government regulations (applicable judicial, legislative and regulatory frameworks), or as part of social marketing and corporate image strategies (ABM, 2020).

González and Gutiérrez (2012) study the impact and perception of CSR in Spain's financial sector; they find that this issue is becoming an increasing concern for financial 
institutions given the need to adequately manage reputational, ethical, social, and environmental risk, as well as the growing pressure from regulatory agencies, government agencies, customers, and society.

It has also been argued that the CSR policies of financial institutions still have a long way to go to meet society's expectations, in that, to date, these policies have failed to fully address prevailing social concerns (Pérez- Ruíz and Rodríguez-del Bosque, 2012).

Another important factor is culture, given that many banks are headquartered abroad. An exploratory study by Barin and Boehe (2010) notes that multinationals can align their CSR programs and projects within a framework that facilitates global integration and builds competitive advantage, based on a contextualized concept that is shaped by the socio-political drivers required to ensure local response capacity (Maon, Swaen \& Lindgreen, 2017). For this reason, it is worth exploring the extent to which the banks included in this study, including transnational corporations, have responded to the needs of the local population in terms of the variables presented here.

As of end of 2004, the regulation of the MFS fell upon the Ministry of Finance and Public Credit (Secretaria de Hacienda y Credito Publico, SHCP), whose oversight responsibilities were discharged by four commissions: the National Banking and Securities Commission (Comisión Nacional Bancaria y de Valores, CNBV); the National Insurance and Bonds Commission (Comisión Nacional de Seguros y Fianzas, CNSF); the National Retirement Savings Commission (Comisión Nacional del Sistema de Ahorro para el Retiro, CONSAR); and the National Commission for the Protection and Defense of Users of Financial Services (Comisión Nacional para Protección y Defensa de los Usuarios de Servicios Financieros, CONDUSEF). But since then the global financial collapse and ongoing globalization, with their associated social costs, have necessitated reforms and restructuring within the sector(Arrazate, 2010; Borboa Álvarez \& Delhumeau Rivera, 2018).

Accordingly, as Muñoz, Fernández, and Escrig (2013) point out, CSR implementation in the banking sector requires a series of obligations, resources, policies, and procedures to achieve the desired results based on commitments in the following areas: sustainability at the heart of the core business; responsibility, assuming the consequences of transaction impacts and risks at the highest level; accountability to stakeholders; transparency; the markets; and governance. This means discouraging inappropriate financial practices and fostering implementation of public regulations that protect social interests based on the corresponding commitment, in order to make an impact on organizational performance.

The theoretical framework requires a focus on a specific regions with a distinctive CSR context, since financial institutions may be conditioned by various organizational influences, internal and external drivers, and other factors that facilitate or hinder the integration of social responsibility (Engert, Rauter \& Baumgartner, 2016) such as corporate governance and the managerial perception of CSR at each bank. Thus, companies might respond differently in different Mexican states or cities, and so it is worth exploring the role of management of banking firms to determine the extent to which they affect the job satisfaction and business performance of each branch. 


\section{Model proposed}

To achieve the aim of this study, a model of causal relationships was constructed based on prior theoretical and empirical analysis, and complemented by the hypotheses presented in Figure 1:

Figure 1. Theoretical research model

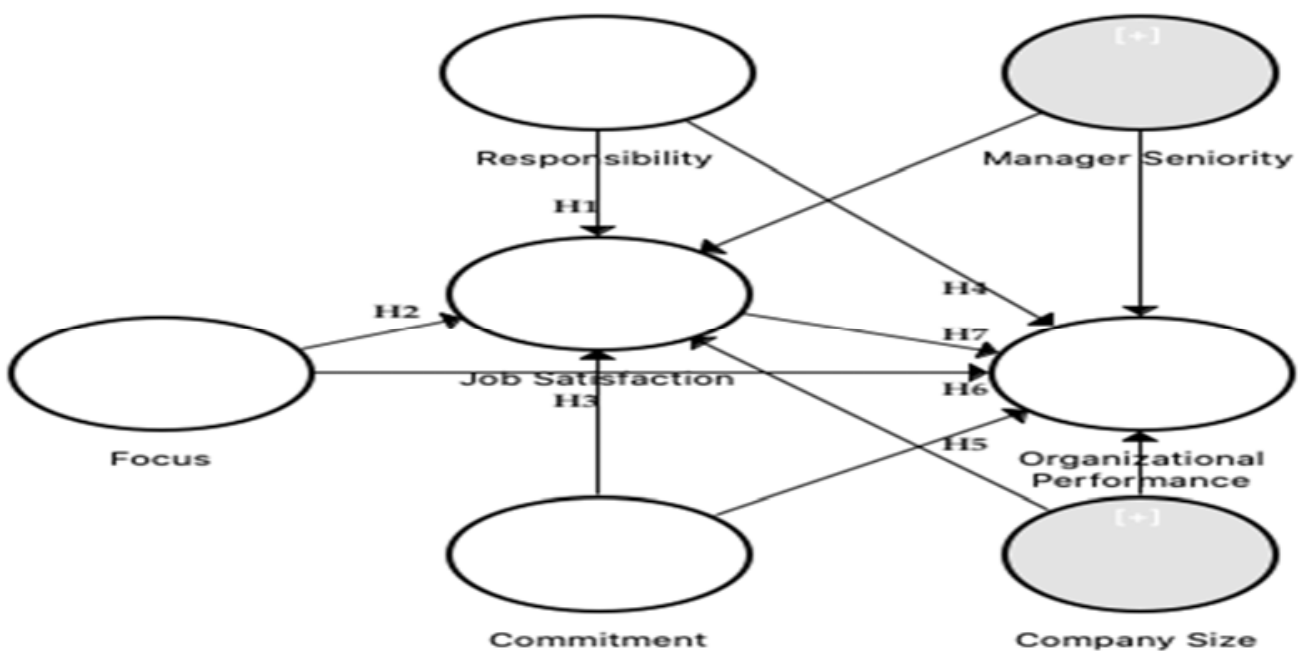

Note: Figure 1 shows the theoretical model and the relationships (hypotheses) structured on management responsibility, focus, and commitment, including the variables of job satisfaction and organizational performance. Moreover, the figure presents the relationship between the control variables (company size and manager seniority) and job satisfaction and organizational performance. Source: compiled by the authors.

\section{Analysis and discussion of hypotheses}

To measure the variables established in the present study from a CSR perspective and, in turn, to develop the hypotheses presented here, the findings of various other authors are taken into account.

\section{Responsibility, focus, and commitment on job satisfaction}

Some empirical studies have found that a company's participation in CSR activities denotes the application by management of organizational norms and values, which influences the perceptions of employees regarding labor conditions within the firm (Backhaus et al., 2002; Greening \& Turban, 2000). Moreover, the various ways in which CSR creates value for stakeholders have been documented. For instance, when company employees act responsibly, they benefit from good practices such as a fair salary, a safer working environment, and professional development opportunities (El Akremi et al., 2018). In turn, these employees experience greater job satisfaction (De 
Borboa-Álvarez, E.P., Valdez Juárez, L.E., Limón-Ulloa, R., Hernández-Ponce, O.E. and Saucedo Monarque, J. (2020) The Role of Responsible Management in Job Satisfaction and Performance Within Banking Firms, Vol.12(1): 82-102

Roeck et al., 2016), express higher degrees of organizational commitment (Ali et al., 2010; Brammer et al., 2007), and involve themselves to a greater extent in organizational citizenship behaviors (Bode et al., 2007; Hansen et al., 2011). Based on these observations, the first hypothesis of this study is as follows:

$\mathrm{H} 1$. The greater the responsibility of company management for socially responsible actions, the higher the level of job satisfaction of employees in the banking sector.

$\mathrm{H} 2$. The greater the focus of company management on socially responsible actions, the higher the level of job satisfaction of employees in the banking sector.

H3 The greater the commitment of management to socially responsible actions, the higher the level of job satisfaction of employees in the banking sector.

\section{Management responsibility, focus, and commitment on performance}

Much of the literature shows that application of CSR initiatives leads to improved company performance and higher returns for stakeholders. Moreover, managers can check that their brands meet the established indicators and develop strategies to ensure their organizations achieve greater support from society, thus obtaining more resources, attracting more volunteers, and improving the services provided-advantages that translate into better social performance (Da Silva et al., 2020). When it comes to the control variables, Gangi, Mustilli, and Varrone (2019) find bank size to be statistically significant, suggesting that larger banks have higher performance levels.

Miralles Marcelo et al. (2012) detect a relationship between CSR and corporate financial performance, affirming that social responsibility is a significant variable that contributes to explaining (albeit with a negative sign) the returns of the Spanish stock market. Conversely, Vishwanathan et al. (2019) and Tang, Hull and Rothenberg (2012) observe a positive association in the same relationship between the same variables (CSRfinancial performance). Maas (2018) confirms that the use of hard quantitative targets can foster significant improvements in CSR, while soft qualitative targets are ineffectual.

Increasing numbers of studies are exploring the various dimensions of CSR. However, relatively few have considered the effects on employees. A study by Turker (2009) reveals that CSR to various stakeholders, employees and customers included, were significant predictors of organizational commitment, as it can be perceived as a requirement for a good working environment. Moreover, it is considered a tool for improving performance (Inoue \& Lee 2011; Erhemjamts, Li, \& Venkateswaran 2013).

Recent studies provide similar evidence, pointing to the positive and significant effects, direct or indirect, of CSR on performance across all groups of firms studied (Jin \& Drozdenko 2010; Tarus 2015; Reverte et al. 2016; Gallardo-Vázquez et al. 2019; Yasir, et al. 2019). These findings prompt the following hypotheses:

$\mathrm{H} 4$. The greater the responsibility of management for socially responsible actions, the higher the level of performance of firms in the banking sector. 
Borboa-Álvarez, E.P., Valdez Juárez, L.E., Limón-Ulloa, R., Hernández-Ponce, O.E. and Saucedo Monarque, J. (2020) The Role of Responsible Management in Job Satisfaction and Performance Within Banking Firms, Vol.12(1): 82-102

H5. The greater the commitment of management to socially responsible actions, the higher the level of performance of firms in the banking sector.

H6. The greater the focus of company management on socially responsible actions, the higher the level of performance of firms in the banking sector.

\section{Job satisfaction and organizational performance}

Flammer et al. (2019) discover that the inclusion of CSR targets in employee compensation leads to an increase in the number of corporate initiatives aimed at benefiting the local community. Other, related studies find that the use of executive compensation linked to CSR generally enhances performance (Derchi, Zoni, \& Dossi, 2020). Based on these results, the present study proposes the final hypothesis:

$H 7$. The greater the job satisfaction, the higher the level of performance of firms in the banking sector.

\section{Methodology}

\section{Research design}

The research design is quantitative, predictive, and non-experimental and focuses on a population of financial-sector companies located in the northwest of Mexico (cities in the states of Sonora and Baja California). The selection of the population follows the principles of the stratified method. CSR in banking is an under-explored field, particularly in this geographical area, and so this focus opens up a wide field of research.

\section{Participants}

To conduct this research, banks operating in the states of Baja California and Sonora were selected based on current membership of the Mexican Banking Association (ABM, 2017). As a selection criteria, the banks had to be engaged primarily in multiple or commercial banking services; this meant that financial institutions dedicated solely to provision of a single service, whether auto loans, mortgages, foreign trade, credit cards, legal services, investment, or insurance, were discarded. Taking this criteria into consideration, the sample was delimited to the banks offering the widest range of services; this left the following 17 firms: Banca Afirme, Banco Ahorro Famsa, Banco Azteca, Banco Compartamos, Banco del Bajío, Banco Inbursa, Banco Mercantil del Norte, Banco Monex, Banco Nacional de México, Banco Regional de Monterrey, Banco Santander, BanCoppel, BBVA Bancomer, CIBanco, HSBC México, and Scotiabank, as those in a position to make the most significant contribution to this study (Borboa Álvarez \& Delhumeau Rivera, 2018). 
The data collection technique entailed the application of a questionnaire in the form of a personal interview with a manager or director at each of the banks that participated in the study.

The fieldwork was carried out from March 2015 to June 2017.

Finally, a total of 85 bank employees were interviewed. The majority, 65.90\% (56 individuals), were male, while only $34.10 \%$ were female (29 individuals). Some authors, such as Hair, Sarstedt, Ringle and Mena (2012); and Roldán and Sánchez-Franco (2012) have stated that a minimum sample of 76 cases is necessary, provided that the reliability and Cronbach's alpha meet the minimum acceptable criteria for the social sciences. Thus, the present study exceeds the minimum number of participants needed to test the proposed model.

\section{Materials}

It was decided to design a questionnaire using Likert-type scaling based on interpretation and application of selected national CSR guidelines, such as those the Mexican Center for Philanthropy (Centro Mexicano para la Filantropía, CEMEFI, 2015; 2017) employs for its corporate social responsibility award, as well as international ones, such as the guidelines of the Organization for Economic Cooperation and Development (OECD, 2013), the model proposed by the Global Reporting Initiative (GRI), the International Organization for Standardization's Guidance on Social Responsibility (1SO 26000), the Ethos Corporate Social Responsibility Indicators (Ethos, 2011), and the labor principles of the United Nations Global Compact (Global Compact, 2010). These were used to validate the questionnaire's suitability for studying the effects of responsible management on job satisfaction and performance among banking firms based in Baja California and Sonora.

The questionnaire was sent to a manager or director at each of the banks. This measurement instrument was divided into three sections: first, a section featuring sociodemographic data about the manager and general data about the bank; a second section containing ten subsections, as described below; and a third section with six open questions to explore in each bank's CSR practices, where applicable, in greater depth. The components of the second section were structured in line with the scales prepared for each variable, with the respective dimensions containing statements and responses based on a five-point Likert scale (1 = "totally agree"; 5 = "totally disagree").

\section{Procedure}

Each item in the questionnaire was subjected to expert content validity based on the content validity ratio proposed by Lawshe (1975), as modified by Tristán (2008). The questionnaire was then applied to bank managers by way of a visit to the workplace of each; this original instrument contained 154 items distributed across the variables under study (Borboa-Álvarez \& Delhumeau-Rivera, 2016). 
Once the experts had completed the content validity, the instrument items were adjusted. Then, a pilot was conducted whereby the final validated version of the questionnaire, which contained the 79 accepted items that achieved a content validity ratio equal to or greater than 0.5823 , was applied to the managers of the selected banks. In this pilot, a small number of banks received the questionnaire to assess its reliability and verify that the scales measured what they were intended to measure. This pilot questionnaire was applied to 17 managers, between 26 and 55 years of age, of 15 banks in the city of Ensenada, and two banks in the city of Tijuana, Baja California, Mexico. None of these respondents were included in the final sample. This yielded positive results; using Cronbach's alpha coefficient, the entire questionnaire was found to have a reliability of 0.948 and an overall content validity index of $89.87 \%$.

Then, data on the final sample of 85 banking firms was obtained through visits to their workplaces; in this case the questionnaire achieved a Cronbach's alpha coefficient of 0.923 across the entire model. Of these, 17 of the banks are based in Ensenada (Afirme, Banamex, BanBajío, Banco Azteca, Banco Famsa, Bancoppel, Banorte, Banregio, BBVA Bancomer, Cibanco, Compartamos Banco, HSBC, Inbursa, Monex, Santander, Scotiabank y Banjercito); and 15 in Tijuana (15 of the 17 banks in that city, excluding Banjército and Banca Monex), both located in the state of Baja California, in the period 2015 to 2016. In the state of Sonora, questionnaires were administered to 15 banks in Guaymas (100\% of the banks operating in that city), to 14 banks in Hermosillo, to 14 banks in Navojoa (likewise $100 \%$ of the banks operating in that city), and to 12 commercial banks in Obregón City, in the first half of 2017 (Table 1).

Table 1. Population composition

\begin{tabular}{lcc}
\hline & No. & $\%$ \\
Ensenada & 17 & 20.0 \\
Tijuana & 15 & 17.6 \\
Guaymas & 15 & 17.6 \\
Navojoa & 13 & 15.3 \\
Cd. Obregón & 12 & 14.1 \\
Hermosillo & 13 & 15.3 \\
Total & 85 & 100.0 \\
\hline
\end{tabular}

Note: Table 1 presents the entire sample of 85 banking firms participating in this study. Source: Compiled by authors.

The two largest categories of managers surveyed are males between 26 and 35 years old, and males between 36 and 45 years old, (each accounting for $23.50 \%$ of the total) as shown in Table 2. Subsequently, the database containing the results of the questionnaire was processed using the SPSS, version 25. 
Table 2. Sex of manager by age range

\begin{tabular}{|c|c|c|c|c|}
\hline & & Male & Female & Total \\
\hline \multirow{2}{*}{$\begin{array}{l}\text { Between } 21 \text { and } \\
25 \text { years }\end{array}$} & No. & 2 & 0 & 2 \\
\hline & $\%$ & $2.4 \%$ & $0.0 \%$ & $2.4 \%$ \\
\hline \multirow{2}{*}{$\begin{array}{l}\text { Between } 26 \text { and } \\
35 \text { years }\end{array}$} & No. & 20 & 12 & 32 \\
\hline & $\%$ & $23.5 \%$ & $14.1 \%$ & $37.6 \%$ \\
\hline \multirow{2}{*}{$\begin{array}{l}\text { Between } 36 \text { and } \\
45 \text { years }\end{array}$} & No. & 20 & 14 & 34 \\
\hline & $\%$ & $23.5 \%$ & $16.5 \%$ & $40.0 \%$ \\
\hline \multirow{2}{*}{$\begin{array}{l}\text { Between } 46 \text { and } \\
55 \text { years }\end{array}$} & No. & 13 & 3 & 16 \\
\hline & $\%$ & $15.3 \%$ & $3.5 \%$ & $18.8 \%$ \\
\hline \multirow{2}{*}{$\begin{array}{l}\text { Between } 56 \text { and } \\
65 \text { years }\end{array}$} & No. & 1 & 0 & 1 \\
\hline & $\%$ & $1.2 \%$ & $0.0 \%$ & $1.2 \%$ \\
\hline \multirow[t]{2}{*}{ Total } & No. & 56 & 29 & 85 \\
\hline & $\%$ & $65.9 \%$ & $34.1 \%$ & $100.0 \%$ \\
\hline
\end{tabular}

Note: Table 2 presents the entire sample of managers participating in this study, broken down by sex and age. Source: Compiled by authors.

\section{Analysis and discussion of results}

According to the classification of the sample of banks, presented in Table 3, 38.80\% (33 banks) are Mexican-owned, while 61.20\% (52 banks) are multinationals, with either with a presence in the Americas (North America and/or Latin America) or globally. Multinationals were found to predominate in all locations, with the exception of Ciudad Obregón, where there were seven banks of each type. 
Table 3. Bank classification by geographical location

\begin{tabular}{lrrr}
\hline Type of bank: & Domestic: & Multinational: & Total: \\
Ensenada & 7 & 10 & 17 \\
Tijuana & 6 & 9 & 15 \\
Guaymas & 4 & 9 & 13 \\
Navojoa & 4 & 9 & 13 \\
Cd. Obregón & 7 & 7 & 14 \\
Hermosillo & 5 & 8 & 13 \\
Total & 33 & 52 & 85 \\
\% Total & $38.8 \%$ & $61.2 \%$ & $100.0 \%$ \\
\hline
\end{tabular}

Note: Table 3 presents an overview of the banks by city. Source: Compiled by authors.

To validate the hypotheses and to verify the effect that management responsibility, focus, and commitment regarding socially responsible actions have on job satisfaction and organizational performance, an OLS linear regression model was used. Specifically, four linear regression models were developed by way of the following equations. The first equation, represented in Model 1 , indicates the influence on job satisfaction $(\beta 0)$ of responsibility $(\beta o)$, company size $(\beta 2)$, and manager seniority $(\beta 3)+£$ (error). In Model 2 , the equation symbolizes the effect on job satisfaction ( $\beta 0)$ of focus $(\beta 1)$, company size $(\beta 2)$, and manager seniority $(\beta 3)+£$ (error). In Model 3 , the equation denotes the influence on job satisfaction ( $\beta 0$ ) of commitment ( $\beta 1)$, company size $(\beta 2)$, and manager seniority $(\beta 3)+£$ (error). The final restructured equation, Model 4 , shows the influence on job satisfaction ( $\beta 0$ ) of performance ( $\beta 0)$, company size $(\beta 2)$, and manager seniority $(\beta 3)+£$ (error).

Model 1 Job satisfaction $i=\beta 0+\beta 1 \times$ Responsibility $i+\beta 2 x$ company size $+\beta 3 \times$ manager seniority $+£$ Model 2 Job satisfaction $i=\beta 0+\beta 1 \times$ Focus $i+\beta 2 \times$ company size $+\beta 3 \times$ manager seniority $+£$ Model 3 Job satisfaction $i=\beta 0+\beta 1 \times$ Commitment $i+\beta 2 \times$ company size $+\beta 3 \times$ seniority of manager $+£$ Model 4 Job satisfaction $i=\beta 0+\beta 1 \times$ Performance $i+\beta 2 \times$ company size $+\beta 3 \times$ manager seniority $+£$

Table 4 presents the equation that expresses the relationship between responsibility and job satisfaction. The results provide empirical support for $\mathrm{H} 1$. According to the values of $(\beta=0.518, p<0.001)$, the greater the managements' responsibility for socially responsible actions, the stronger the positive influence on employees' job satisfaction in the sector. That is, management responsibility for socially responsible actions increases the level of job satisfaction of employees in the banking sector. Moreover, based on the control variables introduced, the results indicate that only company size has a positive and significant influence on the variable of job satisfaction according to the value of $(\beta=0.158$, $\mathrm{p}<0.010)$. On the other hand, there is a correlation with very weak significance between the control variable of manager seniority and the job satisfaction variable, with the value of $(\beta=0.135, p>0.010)$. An adjusted $R$-squared is used to validate the linear regression models of $\mathrm{H} 1$, with a value of $(0.267)$ and $F$ values of $\left(11.174^{\star * *}\right)$. Moreover, the variable 
Borboa-Álvarez, E.P., Valdez Juárez, L.E., Limón-Ulloa, R., Hernández-Ponce, O.E. and Saucedo Monarque, J. (2020) The Role of Responsible Management in Job Satisfaction and Performance Within Banking Firms, Vol.12(1): 82-102

of responsibility (independent) from the linear regression model presents a variance inflation factor (VIF) value close to one of 1.03, thus ruling out the presence of multicollinearity.

It can also be seen that management responsibility for socially responsible actions $(\mathrm{H} 4)$ has a significant and positive relationship on the performance of companies in the banking sector, with a value of $(\beta=0.245, p<0.001)$. The adjusted $R$-squared has a value of $(0.136)$ and an $F$ value of $\left(5.400^{* * *}\right)$. Therefore, the presence of multicollinearity is ruled out.

Table 4. Relationship between: (Responsibility, Job satisfaction and Performance)

\begin{tabular}{ccc} 
Exogenous variables & Endogenous variables & \\
\hline Job satisfaction & Performance \\
Coef. (t value ) & Coef. (t value ) \\
\hline Company size & $0.518^{* *}$ & $0.245^{* *}$ \\
\hline Seniority of manager & $(5.440$ & $(2.368)$ \\
\hline Highest VIF & $0.158^{*}$ & 0.319 \\
F value & $(1.691)$ & $(3.143)$ \\
\hline Adjusted R-squared & 0.135 & 0.055 \\
\hline & $(1.424)$ & $(0.533)$ \\
\hline
\end{tabular}

Note: Table 4 shows the results of the linear regression of $\mathrm{H} 1$ and $\mathrm{H} 4$, the value of the standardized coefficients, and, below them in parentheses, the Student $t$ value. The values of the highest VIF, the F value, and the adjusted R-squared value are also presented. In addition, the levels of significance are presented as: ${ }^{*},{ }^{* *},{ }^{* * *}$ denoting significance levels of $10 \%, 5 \%$, and $1 \%$, respectively. Source: Compiled by authors.

Table 5 represents the relationship between management focus on socially responsible actions and job satisfaction $(\mathrm{H} 2)$, as well as the relationship with performance $(\mathrm{H} 6)$. The empirical results support the notion that management promotion of socially responsible action has a positive and significant influence on the job satisfaction of the staff, with values of $(\beta=0.673, p<0.001)$. These values confirm that the greater the focus of company management on socially responsible actions, the higher the level of job satisfaction of employees in the banking sector. Using the control variables, the results indicate that there is no positive and significant influence for the job satisfaction variable. The linear regression model of $\mathrm{H} 2$ presents the adjusted R-squared with a value of 
Borboa-Álvarez, E.P., Valdez Juárez, L.E., Limón-Ulloa, R., Hernández-Ponce, O.E. and Saucedo Monarque, J. (2020) The Role of Responsible Management in Job Satisfaction and Performance Within Banking Firms, Vol.12(1): 82-102

(0.452) and the $F$ values of $\left(24.105^{\star * *}\right)$. Likewise, in the representation of the results of the $\mathrm{H} 6$ relationship, it can be seen that the value of management focus on socially responsible actions on the performance of companies in the banking sector is strongly significant and positive, with a value of $(\beta=0.439, p<0.001)$, and an adjusted $R$-squared with a value of $(0.269)$, and an $\mathrm{F}$ value of $\left(11.301^{* * *}\right)$. In both models the presence of multicollinearity is ruled out, since both present a value close to one.

Table 5 Relationship between: (Management Focus, Job satisfaction and Performance)

\begin{tabular}{ccc} 
Exogenous variables & Endogenous variables & \\
\hline Focus & $\begin{array}{c}\text { Job satisfaction } \\
\text { Coef. (t value })\end{array}$ & Corformance \\
\hline Company size & $0.673^{* * *}$ & $0.439^{* * *}$ \\
& $(8.189)$ & $(4.624)$ \\
\hline Manager seniority & 0.064 & $0.253^{* * *}$ \\
\hline Highest VIF & $(0.780)$ & $(2.675)$ \\
\hline F value & 0.080 & 0.036 \\
\hline Adjusted R-squared & $(0.990)$ & $(0.389)$ \\
\hline
\end{tabular}

Note: Table 5 shows the results of the linear regression of $\mathrm{H} 2$ and $\mathrm{H} 6$, the value of the standardized coefficients, and, below them in parentheses, the Student $t$ value. The values of the highest VIF, the F value, and the adjusted R-squared value are also presented. In addition, the levels of significance are presented as: ${ }^{*},{ }^{* *},{ }^{* *}$ denoting significance levels of $10 \%, 5 \%$, and $1 \%$, respectively. Source: Compiled by authors.

When it comes to $\mathrm{H} 3$ and $\mathrm{H} 5$, Table 6 presents the results of the equations expressing the relationship between the management's commitment to socially responsible actions and job satisfaction and performance, respectively. The results show that the management's socially responsible commitment has a weak positive and significant correlation with job satisfaction, with values of $(\beta=0.149)$, and, in the case of the control variables introduced, the results indicate a weak correlation value with company size ( $\beta$ $=0.132$ ). As to the variable of manager seniority on the variable of job satisfaction, the value is $(\beta=0.057)$. To validate the linear regression models of $H 3$, an adjusted $R$ squared with a value of $(0.021), F$ values of $\left(1.01^{* * *}\right)$, and a VIF value of 1.01 is obtained. As such, it does not present multicollinearity. For the case of $\mathrm{H} 5$, commitment is found to have a significant and positive effect on performance of banking firms, with a value of 
Borboa-Álvarez, E.P., Valdez Juárez, L.E., Limón-Ulloa, R., Hernández-Ponce, O.E. and Saucedo Monarque, J. (2020) The Role of Responsible Management in Job Satisfaction and Performance Within Banking Firms, Vol.12(1): 82-102

( $\beta=0.324, p<0.001)$, an adjusted $R$-squared value of $(0.089)$, and an $F$ value of $(3.744$ $\left.{ }^{* * *}\right)$. Again, the presence of multicollinearity is discarded.

Table 6. Relationship between: (Management Commitment, Job satisfaction and Performance)

\begin{tabular}{ccc} 
Exogenous variables & Endogenous variables & \\
\hline Job satisfaction & Performance \\
Coef. $(t$ value $)$ & Coef. (t value ) \\
\hline Commitment & 0.149 & 0.114 \\
$(1.369)$ & $(1.087)$ \\
\hline Seniority of manager & 0.132 & $0.324^{\star * *}$ \\
& $(1.602)$ & $(3.115)$ \\
\hline Highest VIF & 0.057 & 0.023 \\
\hline $\boldsymbol{F}$ value & $(0.521)$ & $(0.219)$ \\
\hline Adjusted $R$-squared & 1.01 & 1.01 \\
\hline
\end{tabular}

Note: Table 7 shows the results of the linear regression of $\mathrm{H} 3$ and $\mathrm{H} 5$, the value of the standardized coefficients, and, below them in parentheses, the Student $t$ value. The values of the highest VIF, the F value, and the adjusted R-squared value are also presented. In addition, the levels of significance are presented as: ${ }^{*},{ }^{* *},{ }^{* * *}$ denoting significance levels of $10 \%, 5 \%$, and $1 \%$, respectively. Source: compiled by author

Finally, Table 7 reveals that job satisfaction has a significant and positive influence on the level of performance with values of $(\beta=0.357, p<0.001)$.

Furthermore, in the control variable of company size there is a correlation with performance, with a value of $(\beta=0.265, p<0.001)$. However, in the variable of manager seniority, there is no significant correlation. To validate the linear regression of $\mathrm{H} 7$, an adjusted $R$-squared is obtained, with a value of $(0.204)$ and $F$ values of $\left(8.163^{* * *}\right)$. Moreover, the labor satisfaction variable of the linear regression model presents a VIF value close to one of 1.03 , again ruling out the presence of multicollinearity. 
Table 7. Relationship between Job satisfaction and Performance

\begin{tabular}{cc} 
Exogenous variables & Endogenous variables \\
\hline Performance & Coef. (t value ) \\
\hline Job satisfaction & $\mathbf{0 . 3 5 7 ^ { * * * }}$ \\
\hline Company size & $(3.605)$ \\
\hline Seniority of manager & $\mathbf{0 . 2 6 5 ^ { * * * }}$ \\
\hline Highest VIF & $(2.679)$ \\
\hline F value & -0.004 \\
\hline Adjusted R-squared & $(-0.045)$ \\
\hline
\end{tabular}

Note: Table 7 shows the results of the linear regression of $\mathrm{H} 7$, the value of the standardized coefficients, and, below them in parentheses, the Student $t$ value. The values of the highest VIF, the F value, and the adjusted R-squared value are also presented.

In addition, the levels of significance are presented as:

${ }^{*},{ }^{* *},{ }^{* * *}$ denoting significance levels of $10 \%, 5 \%$, and $1 \%$, respectively. Source: Compiled by authors.

\section{Conclusions}

Based on the objectives of this study, the significance of the relationships proposed in the seven hypotheses was analyzed by way of the theoretical model. The majority were confirmed to be significant, thus fulfilling the objective of determining the influence of management on job satisfaction and performance at banking firms based in northwestern Mexico.

These firms comprised a sample of 85 banks, located in the states of Sonora and Baja California, to reflect an interest in studying commitment to responsible banking as a 
cornerstone of management. Thus, one of the main contributions of the study was to ascertain that the banks studied are at an exploratory stage in the implementation of social responsibility practices, and are aware of the implicit benefits of their actions in terms of job satisfaction and organizational commitment.

This study confirms that the greater the management responsibility for socially responsible actions, the stronger and more significant the positive influence on job satisfaction. Moreover, it shows that banks that practice social responsibility actions achieve significant results in terms of organizational performance. In light of the above, we have responded to the aim of this study, and confirmed each of the hypotheses.

That said, while several studies have examined the effects of job satisfaction across multiple variables, more research is needed to determine specific contextual influences on responsible performance in other sectors. And although this study pointed toward the synergy that exists between CSR and most of the variables studied-which increases opportunities for knowledge creation-there remains much to be studied. Future research might include variables on managers' superiors, or specific indicators to measure leadership, along the lines of Priyankara, Luo, Saeed, Nubuor and Jayasuriya, 2018; Robertson and Carleton, 2018; Lasrado and Zakaria, 2020; llies, Nahrgang and Morgeson, 2007; Kamdar and Van Dyne, 2007; and Tang et al., 2012.

Finally, it is clear that the present study is not without limitations. First, the research was restricted to the banking sector in northwest Mexico, and generalizability may be may limited. Moreover, restrictions of time, location, and availability affected the ability of managers to receive us at their offices. Thus, the sample size might be considered small, and may have skewed the results. But there is still a need to replicate the study in different geographical contexts, types of financial intermediaries, and economic sectors. And, given that some of the banks have a regional or global presence, cultural variables could also be added, while the inclusion of social marketing variables would open the door to further lines of research.

Second, the data were based on the subjective perceptions of bank managers and/or directors, without involving other stakeholders in this first stage. The type of statistical analysis carried out to test the hypotheses (linear regression) should also be borne in mind. To overcome these limitations, future studies should consolidate the conceptual model by including a larger number of constructs. This could be supported by the use of the structural equation approach (variance and/or covariance), which, as Henseler, Ringle and Sarstedt, (2015) observe, is growing in popularity, in order to progress further in this field. 
Borboa-Álvarez, E.P., Valdez Juárez, L.E., Limón-Ulloa, R., Hernández-Ponce, O.E. and Saucedo Monarque, J. (2020) The Role of Responsible Management in Job Satisfaction and Performance Within Banking Firms, Vol.12(1): 82-102

\section{References}

Asociación de Bancos de México (ABM) (2017). La Banca en México: bancos asociados. http://www.abm.org.mx/bancos-integrantes/

Asociación de Bancos de México (ABM) (2018). La banca en México: Responsabilidad Social. https://www.abm.org.mx/responsabilidad-social/

Asociación de Bancos de México (ABM) (2020). La banca en México: marco regulatorio. http://www.abm.org.mx/la-banca-en-mexico/abm-marco-regulatorio.htm

Borboa Álvarez, E. P., \& Delhumeau Rivera, S. (2018). Reforma financiera y la responsabilidad social empresarial en el sector bancario de México. Revista Latinoamericana de Derecho Social, 26(26), 29-88. https://doi.org/10.22201/iij.24487899e.2018.26.11859

Borboa-Álvarez, E. P., \& Delhumeau-Rivera, S. (2016). Validez de contenido de un instrumento para medir la responsabilidad social de las empresas bancarias. RECAI Revista de estudios en contaduría, administración e informática, 5(12), 1-29. Retrieved from https://recai.uaemex.mx/article/view/8927

Carroll, A. B. (1991). The pyramid of corporate social responsibility: Toward the moral management of organizational stakeholders. Business Horizons, 34(4), 39-48. https://doi.org/10.1016/0007-6813(91)90005-G

Carroll, A. B. (2016). Carroll's pyramid of CSR: taking another look. International Journal of Corporate Social Responsibility, 1(1), 1-8. https://doi.org/10.1186/s40991-016-00046

Centro Mexicano para la Filantropía (CEMEFI) (2015). Guía de participación para el proceso de obtención del Distintivo ESR ${ }^{\circledR} 2016$ y Manual de uso de la aplicación para responder el cuestionario diagnóstico. Retrieved on December 04, 2015 from http://www.cemefi.org/esr/images/Guia\%20de\%20participacion\%20Distintivo\%20ESR $\% 202016 \% 20 y \% 20$ manual\%20del\%20sistema.pdf

Centro Mexicano para la Filantropía (CEMEFI) (2017). Informe anual 2016. https://www.cemefi.org/informeanual/index.html

Da Silva, L.C., Mainardes, E. W., Magna, A., Teixeira, C., Júnior, L. C., Br Lindemberg, A., \& Júnior, C. (2020). Brand orientation of nonprofit organizations and its relationship with the attitude toward charity and donation intention. International Review on Public and Nonprofit Marketing, 17, 353-373. https://doi.org/10.1007/s12208-020-00251-6

Engert, S., Rauter, R., \& Baumgartner, R. J. (2016). Exploring the integration of corporate sustainability into strategic management: a literature review. Journal of Cleaner Production, 112, 2833-2850. https://doi.org/10.1016/J.JCLEPRO.2015.08.031

Erhemjamts, O.; Li, Q.; Venkateswaran, A. (2013). Corporate social responsibility and its impact on firms' investment policy, organizational structure, and performance. J. Bus. Ethics, 118, 395-412. https://doi.org/10.1007/s10551-012-1594-x

Flammer, C., Hong, B., \& Minor, D. (2019). Corporate governance and the rise of integrating corporate social responsibility criteria in executive compensation: Effectiveness and implications for firm outcomes. Strategic Management Journal, 40(7), 1097-1122. 
Borboa-Álvarez, E.P., Valdez Juárez, L.E., Limón-Ulloa, R., Hernández-Ponce, O.E. and Saucedo Monarque, J. (2020) The Role of Responsible Management in Job Satisfaction and Performance Within Banking Firms, Vol.12(1): 82-102

Friedman, M. (1970) The Social Responsibility of Business Is to Increase Its Profits. New York Times Magazine, 13 September 1970, 122-126.

Friedman, M. (2007) The Social Responsibility of Business Is to Increase Its Profits. In: Zimmerli W.C., Holzinger M., Richter K. (eds) Corporate Ethics and Corporate Governance. Springer, Berlin, Heidelberg. https://doi.org/10.1007/978-3-540-708186_14

Gallardo-Vázquez, D., Valdez-Juárez, L. E., \& Castuera-Díaz, Á. M. (2019). Corporate social responsibility as an antecedent of innovation, reputation, performance, and competitive success: A multiple mediation analysis. Sustainability (Switzerland), 11(20). https://doi.org/10.3390/su11205614

Gangi, F., Mustilli, M. and Varrone, N. (2019), "The impact of corporate social responsibility (CSR) knowledge on corporate financial performance: evidence from the European banking industry", Journal of Knowledge Management, Vol. 23 No. 1, pp. 110134. https://doi.org/10.1108/JKM-04-2018-0267

González, F. M. T., \& Gutiérrez, R. P. (2012) The impact and perception of corporate social responsibility (CSR): financial sector analysis in Spain 40(1), 14-24

Hair, J.F.; Sarstedt, M.; Ringle, C.M.; Mena, J.A. (2012). An assessment of the use of partial least squares structural equation modeling in marketing research. Journal of the Academy of Marketing Science. 40, 414-433.

Henseler, J., Ringle, C. M., \& Sarstedt, M. (2015). A new criterion for assessing discriminant validity in variance-based structural equation modeling. Journal of the Academy of Marketing Science, 43(1), 115-135. https://doi.org/10.1007/s11747-0140403-8

Inoue, Y.; Lee, S. (2011). Effects of different dimensions of corporate social responsibility on corporate financial performance in tourism-related industries. Tourism Management. 32 (4), 790-804. https://doi.org/10.1016/j.tourman.2010.06.019

Instituto ETHOS (2011). Indicadores Ethos de Responsabilidad Social Empresarial 2011, Sao Paulo, Instituto ETHOS, 2011, http://www1.ethos.org.br/EthosWeb/arquivo/0A-bbe2011_Indic_ETHOS_ESP.pdf

Jin, K.G., Drozdenko, R. \& DeLoughy, S. (2013). The Role of Corporate Value Clusters in Ethics, Social Responsibility, and Performance: A Study of Financial Professionals and Implications for the Financial Meltdown. J Bus Ethics 112, 15-24. https://doiorg.itson.idm.oclc.org/10.1007/s10551-012-1227-4

Jin, K.G., Drozdenko, R. G. (2010). Relationships among Perceived Organizational Core Values, Corporate Social Responsibility, Ethics, and Organizational Performance Outcomes: An Empirical Study of Information Technology Professionals. J Bus Ethics 92, 341-359. https://doi-org.itson.idm.oclc.org/10.1007/s10551-009-0158-1

Lasrado, F., Zakaria, N. (2020). Go green! Exploring the organizational factors that influence self-initiated green behavior in the United Arab Emirates. Asia Pac J Manag 37, 823-850. https://doi-org.itson.idm.oclc.org/10.1007/s10490-019-09665-1

Lawshe, C. H. (1975). A quantitative approach to content validity. Personnel Psychology, vol. $28,563-575$. 
Borboa-Álvarez, E.P., Valdez Juárez, L.E., Limón-Ulloa, R., Hernández-Ponce, O.E. and Saucedo Monarque, J. (2020) The Role of Responsible Management in Job Satisfaction and Performance Within Banking Firms, Vol.12(1): 82-102

Maas, K. (2018). Do corporate social performance targets in executive compensation contribute to corporate social performance? Journal of Business Ethics, 148(3), 573-585.

Maon, F., Swaen, V. \& Lindgreen, A. (2017). One Vision, Different Paths: An Investigation of Corporate Social Responsibility Initiatives in Europe. J Bus Ethics 143, 405-422 https://doi-org.itson.idm.oclc.org/10.1007/s10551-015-2810-2

Miralles Marcelo, J. L., Miralles Quirós, M. del M., \& Miralles Quirós, J. L. (2012). Performance bursátil de las empresas socialmente responsables. Cuadernos de Economía y Dirección de La Empresa, 15(4), 221-230. https://doi.org/10.1016/j.cede.2012.06.002

Morata, F., Vilá, B. y Suárez, C. (2010), La Responsabilidad Social de la Empresa a debate: lecciones de la crisis Una perspectiva europea. Spain: Institut Universitari d'Estudis Europeus. IUEE-UAB. ISBN-13:978-84-95201-27-0 y ISBN-10: 84-95201-275

Muñoz Torres, M., Fernández Izquierdo, M., \& Escrig Olmedo, E. (2013). Responsabilidad social corporativa e internacionalización bancaria: el caso de la banca española en Argentina, Brasil y Chile. Harvard Deusto Business Research, 2(2), 143164. doi:10.3926/hdbr.18

OECD (2013), Líneas Directrices de la OCDE para Empresas Multinacionales, OECD Publishing, Paris, https://doi.org/10.1787/9789264202436-es.

Pacto Mundial. (2010). Principios laborales del Pacto Mundial de las Naciones Unidas. Guía para empresas. Ginebra, Oficina Internacional del Trabajo, 2010 ca. 30 p. https://www.pactomundial.org/wp-content/uploads/2015/04/ppios-laborales-delPactoMundial-guia-para-empresas.pdf

Reverte, C.; Gómez-Melero, E.; Cegarra-Navarro, J.G. (2016). The influence of corporate social responsibility practices on organizational performance: Evidence from eco-responsible Spanish firms. J. Clean Prod. 112 (4), 2870-2884

Roldán, J.L.; Sánchez-Franco, M.J. (2012). Variance-based structural equation modeling: Guidelines for using partial least squares. In Research Methodologies, Innovations and Philosophies in Software Systems Engineering and Information Systems; Mora, M., Gelman, O., Steenkamp, A.L., Raisinghani, M., Eds.; Information Science Reference: Hershey, PA, USA. 193-221.

Sánchez, P. E., De la Cuesta-Gonzalez, M. \& Paredes-Gazquez, J. D. (2017) Corporate social performance and its relation with corporate financial performance: International evidence in the banking industry. Journal of Cleaner Production, 162, 1102-1110. https://doi.org/10.1016/j.jclepro.2017.06.127

Tang, Z.; Hull, C.E.; Rothenberg, S. (2012). How corporate social responsibility engagement strategy moderates the CSR-financial performance relationship. J. Manag. Stud. 49, 1274-1303.

Tarus, D.K. (2015) Corporate social responsibility engagement in Kenya: bottom line or rhetoric? Journal of African Business. 16 (3), 289-304.

Tristán, A. (2008). Modificación al modelo de Lawshe para el dictamen cuantitativo de la validez de contenido de un instrumento objetivo. Avances en medición, vol. 6(1), 37-48. 
Turker, D. (2009). How Corporate Social Responsibility Influences Organizational Commitment. J Bus Ethics 89, 189 https://doi-org.itson.idm.oclc.org/10.1007/s10551008-9993-8

Vishwanathan, P.; Van Oosterhout, H.J.; Heugens, P.P.M.A.R.; Duran, P.; Van Essen, M. (2019). Strategic CSR: A concept building meta-analysis. Journal of Management Studies. https://doi.org/10.1111/joms.12514

Yasir Ali, H.; Qaiser Danish, R.; Asrar-ul-Haq, M. (2019) How corporate social responsibility boosts firm financial performance: The mediating role of corporate image and customer satisfaction. Corporate Social Responsibility and Environmental Management https://doi.org/10.1002/csr.1781 